\section{甲状腺腫大が誤診を招来した 食道癌症例}

\section{* 堤 昌已}

食道癌の存在が甲状腺腫大を招来して, これ に接して下方に位置する食道癌を掩蔽して誤診 を招き，併せて食道直達鏡検査後食道第孔性周 囲膿瘍を惹起した興味ある症例に遭遇し，之等 を剖検により確認し得ましたので，ここに報告 する。

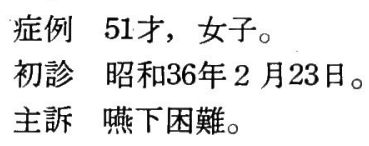

既往歴 子宮筋腫にて36年 1 月に胵上部切断 術を施行。

家族歴 特記すべき事なし。

起始及経過 昭和 35 年 8 月頃より咽喉頭部に 異物感を生じ, 某耳鼻科医により受診の結果, 異常を認められず, 併し德下困難は次第に増強 した。昭和 35 年 12 月には固形物の通過不能とな り, 昭和 36 年 1 月に至り某内科医を訪れて食道 造影, 透視等の諸検査を受けたが, 異常なしと 云われた。併るに其の後 2 ケ月に亘つて依然と して通過障害が存し, 流動食の搑取を続け遂に 本年 2 月（昭和366年）に至り吾々耳鼻科外来を 訪れた。

写悬 1

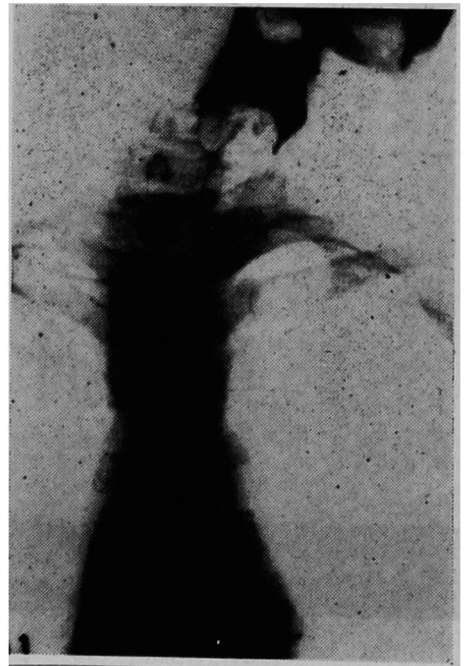

* 慈恵医大耳鼻咽喉科教室（主任教授高橋良）
初診時所見 前頸部の㢼漫性軽度腫大のみを 外部より触れ, 頸部淋巴腺腫大其の他に異常所 見は認められなかつた。間接喉頭鏡下にて梨子 状䙤より被裂部にかけて軽度浮腫状を呈するの みで声門附近には著変は認められなかつた。

同年 3 月 3 日に食道造影を施行してて(写真 1) に示す如き狭窄像を得たので, 次いで食道直達 鏡検査を行つた。

食道鏡所見 上門歯より $16 \mathrm{~cm}$ の部に（写真 2 ) の如き食道壁の左側後壁に拇指頭大の腫廈 を認め, 更に内視鏡を下方へ進める事は不可能 であり,この部の試験拑除をなし，(写真 3 )に 示す如き甲状腺組織であり, 一部軽度の炎症が あるのみの所見を呈した。次いで患者は直達鏡 の抜去後, 食道穿孔性周囲炎と思われる症状を 続発し, 止むなく救急入院を命じ, 抗生剂, 其 の他の治療を施した。
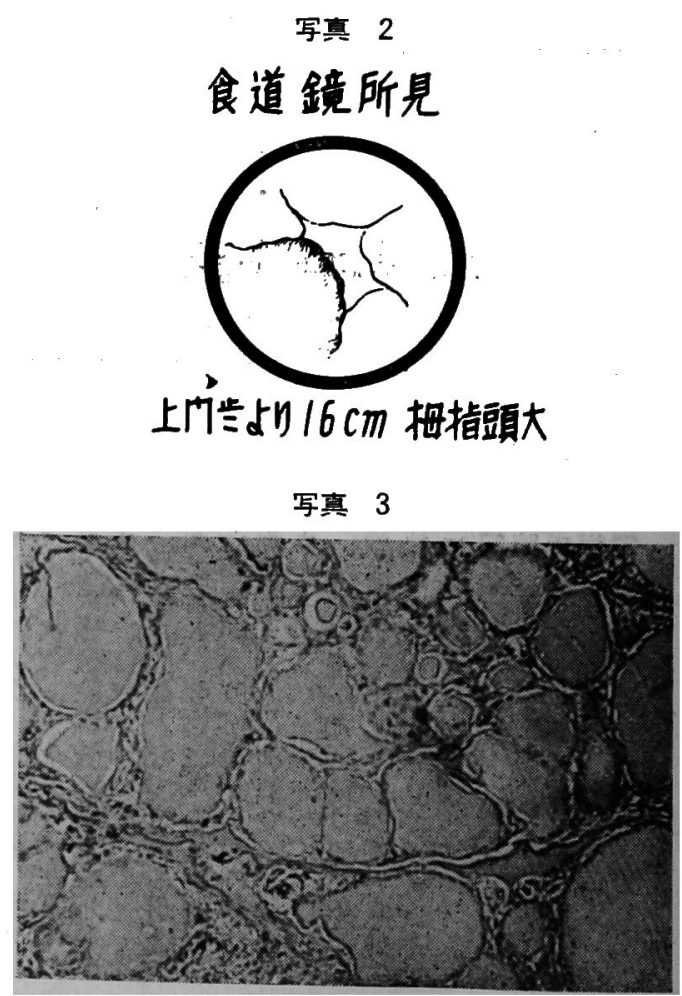

入院後の経過 かくて入院後 4 日にして急性 症状消退したので頸部外切開を行つたが，これ によると，甲状腺の左葉が浅在及び深在性の 2 葉に分れて腫大を示し，その間に膿煬の形成が 
認められた。又深在性に腫大したものの尖端は 食道左後壁にまで広く伸びて食道壁に癒着して 居り,この部分で甲状腺を離断除去し, “術創に ゴムドレーンを立て一方食道には栄養留置カテ ールを置いて術を終えた。術中に採取した甲状 腺の組織検索の結果は前回同様正常甲状腺であ つた。術後経過良好で約 1 時間にて平常状態に 復し, 其の後も軽減した疎通障害, 其の他の一 般状態の経過により治癒するものと考えられた が，術後 23 日に突然 $39^{\circ} \mathrm{C}$ に及が熱発と同時に 左頸部の発赤, 腫脹を生じ, 白血球数 10,600 と なり，再化膿を思わせる症状を呈した。大量の 抗生剤, 補液を 6 日間続けた後, 腫脹部に小切 開を加えたところ多量の排濃を見て, 発熱, 其 の他の急性症状は治癒したが, 尚切開部よりの 持続的排膿が見られ，加えて固形物に対する疎 通障害が次第に増強した。4月27日に至り再び 食道直達鏡検查を行ったところ, 上門歯より $18 \mathrm{~cm}$ の部に渎漫性腫陙様の狭窄が 認められた ので, 外部よりの再度の切開を加えて食道周囲 の探索を行つた。術所見によると，甲状腺の中 等度腫大が存し, 甲状腺の右側稍々深部に癌性 と思しき浸潤が見られ，更に之に接して食道癌 様の腫瘍が発見されたので, 其の鲻にして術を 止めたが, 其の後, 患者は次第に全身衰弱を来 たし遂に死の転帰をとるに至つた。病理検索の 結果, (写真 4 )の如き癌腫が証明され, 又剖検

\section{写真 4}

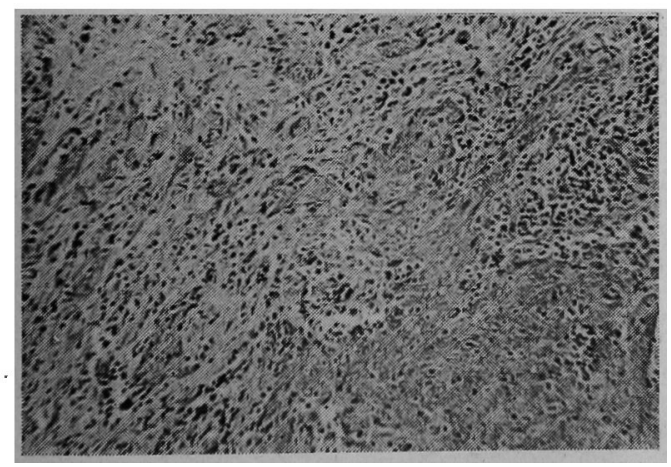

により原発食道癌と腫大甲状腺との関係を明ら かに知り得たものである。(字真 5 に示す)

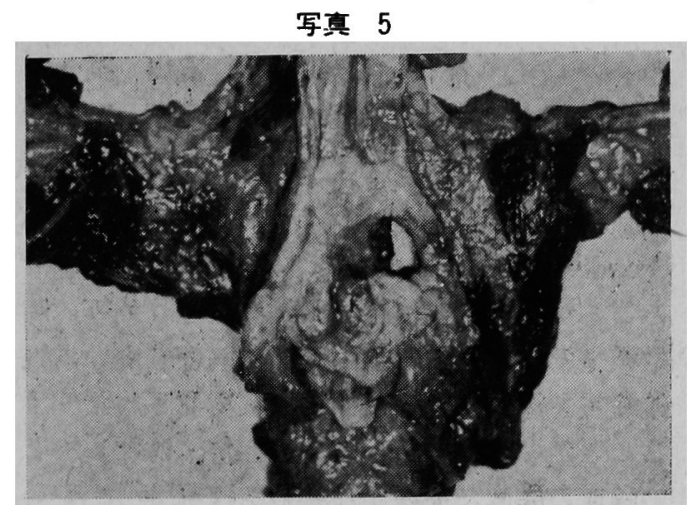

考接 本症例を顧みると, 先づ第 1 回目の内 視鏡検查時に試験拑除を行つて食道穿孔を起し た点については, 本症例の如く実質性腫大を来 たした甲状腺が食道後壁にも及ぶ所見を呈し， 食道粘膜と共に一部突出して, 一見悪性腫瘍を 思わせる像を呈するものは，文献上にも類似例 は数少い様であるが，高原高三教授による剖検 例報告に, 悪性甲状腺腫にて巨大な褧腫と独立 せる壊疽洞を伴い，食事中に魚骨による食道穿 孔を起したと思われるものがあるが，これにて は巨大な霍腫により喉頭, 気管, 食道が反対側 に圧迫され食道壁を圧迫萎縮せしめ, 壁の脆弱 となつた時期に魚骨により岈孔を起こし, 壊㾝 洞を作つたものであろうとの事である。

更に本症例では食道周囲膿㿟の症状を反復 し，加えて疎通障害漸増を示したが，これに対 して膿瘍患部の完全搔把を期して再度の外切開 を行つて, はじめて正確な診断がつくに至つた のである。即ち, 原発食道癌の浸潤が及んで更 に上位の甲状腺の腫大を来たして, 疎通障害の 主要因となり，併せて内視鏡試験拑除による食 道穿孔を起こした結果食道周囲膿痬を惹起して 重ねて誤診を招く結果となつたものと思われ た。 


\section{ABSTRACTS}

\section{Cosideration of Metamorphosis and Progress of the Growth of Pulmonary Carcinoma.}

\author{
Kazuyuki Narabayashi \\ Department of Radiology, Kobe Medical \\ College
}

The Röntgenograms of 456 cases of pulmonary carcinoma were examined on the morphologic alternation of tumor growth, comparing with the pathological findings of 61 cases which were confirmed on operation and autopsy. Especially such cases which happened to have been observed the progress of new growth for a while, were followed up and overtaken, so that the basi cearly diagnosis of the pulmonary carcinoma may be established.

I. The form and localization of the primary origin.

145 cases in which the tumor is less than 3 cm in diameter were selected. The well defined nodular or granular forms are the most common. $(44.1 \%)$. The cases which show the infiltrating linear shadows radiated from hilum are $40 \%$. (Fig. 1, 2) In the early stage when the size of the tumor is small, $45.5 \%$ are found in the hilum and $54.5 \%$ in lung parenchyma. However, $86.2 \%$ of the nodular type of tumor are located in the lung parenchyma and $78.1 \%$ of the infiltrating type are in the hilum. (Table 3 ) Of 10,942 cases of inflamatory disease which are considered having the relationship with the genesis of pulmonary carcinoma, 8 cases are found to be carcinoma. One should be strict and cautious to confirm the site of genesis of a tumor, if the inflamatory lesion or scav can become the originating ground of a tumor.

II. Growth rate of a tumor.

The growth rate of a tumor in which the size is less than $3 \mathrm{~cm}$ was examined. 61 cases which happened to follow up the progress of growth of tumor periodically were selected. The average growth rate in a month is $3 \mathrm{~mm}$. (Table 6)

III. Metamorphosis of the tumor.

The mode of metamorphosis of 86 tumors was roentgenologically investigated and followed up for more than 10 months. The results are shown in Fig. 6.

The cavity formation of pulmonary carcinoma is seen in $38(9 \%)$ out of 418 cases. It was found at about 2 years and 1 month after the first discovery of the tumor. In $2 \%$ an early cavity formation was found.

As for the secondary phenomenon, atelectasis, (36. 3\%), pneumonia (13.5\%) and abscess (6\%) are shown in order of occurence.

IV. Pathological consideration.

Some patholooical and roentgenological consiedration. were performed with the nodular and infiltrating type of tumor which originated in the hilum and lung parenchyma. Some tumors were found to infiltrate, adhere and encircle the pulmonary vein, and the tumors originated from the subpleural region or adjacent to the mediastinum. (Fig. 10-16

V. The search for the alveolar cell carcinoma.

43 cases of alveolar cell carcinoma were searched for by means of observing some serial roentgenograms and some specimens of autopsies. $41.8 \%$ of them were found having multiple lesions without evident origin, $25.6 \%$ multiple lesions with suspicious origin, and $32.6^{\circ} \%$ localized origin. (Fig. 17)

The differentiation of alveolar cell carcinoma as a monopolar originating tumor with multiple intrapulmonary metastases or multipolar originating tumors was not elicited. However, if it were found earlier, the possibility of the determination of its origin would have been increased.

\section{Acase of Esophagus-cancer Misdiag- nosed Because of Enlarges Thyrord}

\section{Masami Tsutsumi M. D.}

Tokyo Jikei University School of Medicine, Department of Otorhinoearyngology.

On esophagoscopy, just below the mouth of the esophagus a smooth tumor which appeared to be ovoid in shape and hard in consistency. A few small fragments af tissue were removed 
for microscpic examination. The specimen showed thyroid tissue.

Acute symptoms of esophageae perforation followed immediately after the biopsy.

The acute symptoms were abated One later. Cancer was subsequently discovered just below the thyroid swelling by esophago tomy.

The esophagus-cancer was coscealed by thyroid swelling. It was impossidle to discover it with esophagoscopy.

\section{A Casce of Tracheopathia chondro- osteoplastica}

Otohiko Takyama, Yoshihiko Murakami,

Eiichi Ishiyama, Katsuhiko Ito

From the Department of Otorhinolar-

yngology, Nihon University School of

Medicine

Authors unexpectedly observed unusual findings similar to the so called Tracheopathia chondroosteoplastica on a patient, female aged 40, who recently visited the Outpatient Dept. of Oto-rhinolaryngology at Itabashi Hospital of Nihon University with complaint of bloody sputum, and an examination of bronchoscopy was performed.

The authors herein report this case and attempt to give some considerations to literature of this disease.

\section{Clinical Studies of Broncho-genic Pulmonary Cyst}

Suetoku Asai, M. D. and Shigeto Ikeda, M. D.

Sugical Department, School of Medicine, Keio University

Clinical studies have been made upon 10 cases diagnosed as bronchogenic pulmonary cyst according to Kumagai's classification. The 10 investigated cases are comprised of 2 cases of solitary cyst. 5 cases of them underwent pneumonectomy and other 5 cases were lobectomized.

Clinical findings of these cases of bronchogenic pulmonary cyst in comparison with those of cases of bronchiectasis are as follows :

1) As to subjective symptoms, cases of bronchiectasis generally complain of accumulated sputum and cases of bronchogenic pulmonary cyst of ten either have no complaint of sputum or fall into suddenly developing dyspnea in their twenties.

2) In radiological findings, cases of bronchiectasis generally show accentuated linear shadow consisting of pulmonary vessels and bronchi radiated from hilum, and cases of bronchogenic pulmonary cyst generally show honey-comb like shadow.

As to indication of the surgical treatment for bronchogenic pulmonary cyst, pulmonary resection is considered to be effective with consideration of pulmonary function in cases with remittent inflammation or with cysts scattered widely in the unilateral lung.

\section{Treatments of Inflammatory or Neu- rotic Horseness.}

\section{S. Aihara}

Tokyo Woman Coll.

Group A : predonin

The patients consisted of 7 cases of chorditis nodosa, 6 cases of laryngeal polypus and 5 cases of prolapsus ventriculi laryngis, among which 15 cases are cured.

\section{Group B : ATP}

The patients consisted of 7 cases of internusparesis. 2 cases of phonasthenia, 3 cases of chronic laryngitis, one case each of functional aphonia and total paralysis of the recurrent laryngeal nerve.

As the method of treatment, ATP $200 \mathrm{mg}$ was used in one course.

All cases showed alleviation or recovery.

\section{Esophagoscopic Views of the Thoracic Esophageal Diverticula}

Seiichi Kawata and Okio Mukuno

From the Department of Otorhinolaryngology (Director : Prof. S. Kawata, M.

D.), Kyushu University

The authors performed esophagoscopic examination in the cases of thoracic esophageal diverticula and classified into three types according to esophagoscopic views.

In the first type a pouch diverged from the esophageal lumen, the entrance of which was slitshaped or oval, and there was a carina between the esophageal pouch diverged from the lumen 